\title{
The international history of European integration in the long 1970s. \\ A round-table discussion on research issues, methodologies, and directions
}

\author{
Research Reports - Rapports de recherche-Forschungsberichte
}

\section{Introduction}

On 17 December 2010 an unusually heavy snowfall blanketed but did not disrupt a workshop hosted by the History Department of the European University Institute. We had gathered to discuss the international dimensions of European integration. Organizers and participants started out from the obvious consideration that the history of European integration in the 1970s intersects with multiple, too often separated and fragmented threads of ongoing historical research on the Cold War, post-colonialism, globalization, and other international and transnational history subfields. Should European integration be framed and contextualized in this large, unwieldy and rapidly evolving cluster of research fields? And how can we best go about it?

Of course, there are very good reasons simply to advance integration history per se, but should we not also contextualize it, and possibly re-conceptualize it, in view of the rapidly changing international environment, the challenges it raised, and the responses it elicited? New intellectual approaches might be helpful, perhaps even necessary, in order to address the increasingly relevant external dimension of European integration. It obviously affected many, if not most of the crucial policy options, and came to bear from all sides on the new thrust towards the fashioning of a European identity and model.

For those working at EUI, the workshop rounded up a semester-long seminar on the recent historiography of European integration during which students - not necessarily integration specialists - had occasionally questioned the extent to which EC institutions, policies and culture really mattered in the larger scheme of things. The question can be uncomfortable for integration scholars, but it is not an unfamiliar one. It is often voiced - or at least politely implied - in many adjacent fields of international and transnational history, and we might as well face up to it openly and squarely.

It is often lamented that European integration hardly appears in narratives of the Cold War, and just marginally in historical accounts of the waning of Communism, the rise and fall of the Third World project, or the restructuring of international economic flows and policy regimes over the last third of the $20^{\text {th }}$ century. Nor do we directly affect ongoing investigations on the post-imperial redefinition of European societies and polities, with its complex, controversial reorganization of public culture 
in multi-racial terms. We deal, of course, with the genealogy of the "civilian power" notion, but how do we relate it to the long-term, culturally deeper and socially wider shift away from the warfare authority of the European state to its welfare-centred allegiance?

These and several other possible examples illustrate the conundrum highlighted by many recent efforts to reflect on the state of the field, its intellectual make-up, methodological range, and potential developments. ${ }^{1}$ That is to say, how can European integration and its historiography sustain and expand a mutually enriching dialogue with contiguous disciplines, and with the various historical fields and subfields that insist on the same time-period and conceptual territory, from modern European history to international and transnational history of the late 20th century?

One of the paths potentially conducive to such a broader contextualization of European integration's history (certainly not the only relevant one, but a rich option nonetheless) resides in the many aspects of its international relations, transnational associations, and global correlations. Not the least because many integration history's practitioners habitually interrogate and explore the inverse relationship. That is to say, how global or even more geographically and conceptually limited transformations - whether in the security, economic, technological or political and cultural realm - affected the pace, nature, geometry and self-perception of integrative processes.

The discussion at the EUI workshop was kicked off by four of these practitioners, each one having just authored or being about to publish works addressing the main areas of Western Europe's relations with the larger world in the era of détente. Their assigned task was to sum up the most recent scholarly acquisitions, point out the unsolved or controversial conceptual and historiographical issues, and sketch out new promising research directions as well as their inherent dilemmas. The papers they submitted are now presented here as a succinct roundtable debate, after revisions that profited from the insights and comments received by the audience and especially by discussants Mark Gilbert, Wilfried Loth, Piers Ludlow, Kiran Patel and Antonio Varsori. We thank them for their intellectual contribution.

Each of the presenters is advancing useful suggestions specifically related to her/ his distinct angle and terrain. Fellow specialists will no doubt consider them in their own rights. When taken together and read against each other, however, these four voices coalesce around a few assumptions, if not yet a set of common themes, that cut across the various areas of enquiry. They sketch out a shared methodological language and bring forth a comprehensive, albeit still embryonic, analytical framework.

1. See W. KAISER, A. VARSORI (eds.), European Union History: Themes and Debates, Palgrave Macmillan, Houndsmill, 2010; W. Loth (ed.), Experiencing Europe: 50 Years of European Construction 1957-2007, Nomos, Baden-Baden, 2009; M. RASMUSSEN, A.-C. KNUDSEN (eds.), The Road to a United Europe: Interpretations of the Process of European Integration, P.I.E. Peter Lang, Bruxelles, 2009. 
To begin with, none of the four areas can be truly assessed in isolation. They interfere with each other in an extremely dense, intricate compact. It's a reflection of the broad, systemic changes that defined the 1970s as an era of transition between the waning postwar order and the new solutions that consolidated thereafter. Challenges were constantly reassessed; options frenetically compared, interwoven, revised; solutions reached by the unpredictable interactions between multiple, interconnected negotiating tables. There is a resemblance here with the formative era of the integration process, whose emerging shape had to be studied within the foundational stream (and the cross-feeding strands) of reconstruction, pacification, transAtlantic relations, the building of the Cold War architecture, the refashioning of the European nation-state, and the interplay among political cultures.

The 1970s too were a creational moment, with (almost) everything in play at the same time, and a fluid morphing of established categories into as yet undetermined possibilities, paradigms, and priorities. But of course there were anchors too, the welltrodden paths and institutions already in operation, to be preserved and adapted rather than revolutionized. Thus, the scenarios were numerous but not infinite. Yet, many different combinations could have emerged.

It follows that we are called to focus not so much on linear reconstructions of the policies eventually adopted (with the inherent risk of teleology) as on the moments when options - conceptual no less than operational - were confronted, combined, and sifted; on the crucibles where possibilities were dissected and reassembled; on the give and take among different tables, fields and actors. It is certainly no coincidence that, faced with flow and indeterminacy, the four authors prioritize a dialogue with the inclusive narratives of a broad range of historians upon methodologies geared to the modelling of social scientists.

Apparently undaunted by the scale of the ambitious prospect they are charting, they are inviting us to consider the history of European integration as one and all with the history of Europe, and of its shifting place in a changing world.

Federico Romero (European University Institute)

\section{Integrating an international political economy dimension into European integration history: the challenges of the $1970 \mathrm{~s}$}

For anyone interested in international political economy (IPE), the fact that European integration is embedded in global influences is, arguably, a given. Economic and monetary phenomena do not really know borders - or at least not in the same way as other fields of foreign policy and cooperation do. As a consequence, taking into account the global context in the study of European developments largely goes without saying. Talking of European monetary cooperation without mentioning the breakdown of the Bretton Woods system, explaining various European monetary policies 
without mentioning the influence of Milton Friedman and the Chicago school, or the US administration's "neglect" of the dollar in the late 1970s, would be fairly pointless. To put it the other way around: had the US been more amenable to aligning its economic and monetary policy with the German one, the European Monetary System (EMS) would probably not have been created. Keeping this in mind, this article will briefly set out the state of the field, outline some of the problems/methodological challenges to historical research on the 1970s and finally sketch some potential research directions.

Monetary cooperation in general and the breakdown of Bretton Woods, the Werner Plan and the EMS in particular, are now well covered. Many studies have been devoted to the early part, 1969-74, as well as on the EMS. ${ }^{2}$ In a wider chronological perspective, Dimitri Grygowski (who studied the US attitude towards European monetary cooperation), David Marsh (who investigated the birth of the euro) or the work led by Frédéric Clavert on central bankers have also brought significant additions to our knowledge. ${ }^{3}$ The backdrop of increasing globalisation was studied by Harold James, and more recently discussed in Niall Ferguson's edited volume. ${ }^{4}$ And the question of globalisation is indeed a fundamental one since it increased precisely at a time when it was feared that it would stop again, just like in the 1930s - this parallel will be dealt with in some more detail below. A lot still has to be done on the purely economic history side of the 1970s, however: what was the impact of the oil shock on Western European economies? How can we explain that Germany, France, Britain and Italy performed so differently?

\section{Problems and methodological challenges}

In studying those issues, at least five problems/methodological challenges face historians of IPE in the 1970s. A first one is linked to the teleological take of European integration analysis. The 'teleological issue' has recently been raised by Mark

2. See for instance A. BOTTEX, La mise en place des institutions monétaires européennes (1957-1964), in: Histoire, économie et sociétés, 4(1999), pp.753-774; P. LUDLOW, The Making of the EMS. A case study of the politics of the European Community, Butterworth Scientific, London, 1982, E. MOURLON-DRUOL, The Emergence of the European Monetary System, Cornell University Press, Ithaca, 2012.

3. D. GRYGOWSKI, Les États-Unis et l'unification monétaire de l'Europe, Peter Lang, Brussels, 2009; D. MARSH, The Euro. The Politics of the New Global Currency, Yale University Press, New Haven; 2009, F. CLAVERT (ed.), Banquiers centraux et construction européenne, special issue of Histoire, économie et sociétés, forthcoming fall 2011 (see also www.ena.lu for more details on the project).

4. H. JAMES, Rambouillet, 15. November 1975. Die Globalisierung der Wirtschaft, DTV, Munich 1997; N. FERGUSON et al. (eds), The Shock of the Global: The 1970s in Perspective, Harvard University Press, Cambridge, 2010. 
Gilbert. $^{5}$ A teleological approach to IPE in the 1970s is both problematic and challenging. It is problematic because European integration is not a self-evident "good". It is not obvious, for instance, that the EMS was an advance or a progress. When hearing people talking about the British decision not to join the EMS, I still have the impression that the underlying assumption is that the British were wrong in doing so: once again, they would have "missed the bus". At the very least this is debatable. Would it really have been good for the British economy to join the EMS in 1979? Was not the British government genuinely having a different vision of economic and monetary policy at the time, more focused on the necessity to have actual economic convergence prior to monetary unification? The teleological issue is also challenging because it forces to go back to more technical economic and monetary debates. One example, taken from contemporary discussions, can help clarify this point. Analysing the discourse of those against the euro today (or even those against the Maastricht Treaty in the early 1990s), one can observe that they do not necessarily want to leave the euro altogether - or that they did not want any kind of European monetary unification. What they often do not want is the euro to be the single currency in circulation. They instead want the euro to become a common or parallel currency, and reintroduce the use of national currencies. And this discussion actually echoes not only what happened in the 1970s but also in the 1980s and early 1990s: there was a very fascinating debate about the inception of a parallel currency. Yet this debate is usually largely overlooked, because it is technical, because it went nowhere, because of the EMS success story, and finally because it was largely confined to academic economists while the traditional view of the period is that the stars were Valéry Giscard d'Estaing and Helmut Schmidt. But it does matter to study it. We need to get away from a linear success-story going from the EMS to the single currency. And we need to do this because the 1970s was a decade where this range of options did exist. It is hence important to think of the 1970s not only in terms of what was achieved the EMS - but also in terms of what was not achieved, and why. It would also help to go back to a slightly more intellectual history of European cooperation - what it should be doing, or put it differently: what different people think it should be doing, and why they think so.

Another potential difficulty for this period is the perennial question of the difference between what is actually happening and the perception we have of it. To be sure the same problem holds true for other periods of history. But with the 1970s it is particularly salient, with the rise of unemployment and double-digit inflation. It is indeed quite impressive to read the discourses of the time. One could easily find back declarations of Schmidt or Giscard saying that unemployment has reached unacceptable levels, and that they really feared a social explosion etc. In 1975, the level of unemployment in France is 4\%, roughly the same in Germany, 5\% in Britain, 6\% in Italy, $8 \%$ in the US and $2 \%$ in Japan. Of course what matters was the overall evolution: for instance in 1973, unemployment in the UK was at $3 \%$ and three years later

5. M. GILBERT, Narrating the Process: Questioning the Progressive Story of European Integration, in: Journal of Common Market Studies, 3(2008), pp.641-662. See also A.S. MILWARD, Etats-nations et Communauté: le paradoxe de l'Europe?, in: Revue de Synthèse, 3(1990), pp.253-270. 
around $6 \%$, so it had roughly doubled. But this remains figures one would love to have today. Conversely, after having known years of low inflation, I am not entirely sure that we all grasp what $24 \%$ of inflation in 1975 in the UK really meant - nor the extent to which it explains the current obsession of many policy-makers with inflation. Overall, there is thus a very important "psychological" dimension to the study of IPE in this period, since this time was dominated by many fears (unemployment, inflation).

Linked to this is the parallel with the 1930s. The crux of the interwar period was the "dual crisis": the simultaneous collapse of the international economic system and the international political system. ${ }^{6}$ Be they mistaken or not, many leaders in the 1970 s feared that just the same would happen again. As a consequence, another aspect which has also in many respects sociological or psychological undertones was the rise of summitry. To a large extent, the inception of the G7 and the European Council was aimed at creating/maintaining/fostering trust among Western/EEC leaders. This is why summitry was institutionalised: to ease and improve cooperation in times of turmoil. Of course it did not go far sometimes, and it just appeared as claptrap. But at least there was some attempt at cooperating in an international forum to discuss political economy - which did not really exist in the 1930s.

A fourth major challenge, derived from the previous one, is that economic and monetary problems lie at the heart of the 1970s. Of course these issues mattered before, and they still matter after. But the shocks of the 1970s were very peculiar. Set aside the fact that the slowdown of Western economies in the 1970s was to certain extent bound to happen, a series of crucial adaptations happened at that time: the eventual collapse of the Bretton Woods system; the oil shock; the resultant macroeconomic problems (unemployment and inflation exploded) and the feeling of political insecurity associated with it. A critical problem for any historian working on the 1970s is therefore to engage with these economic and financial issues. Yet, the discipline of economic history, in some European countries, particularly France and Britain, is in manifest decline in comparison with the rise of social science analyses or cultural, gender and post-colonial histories. But I truly don't think that one can do any decent history of the decade without having a grasp of its economics. As Lawrence Black and Hugh Pemberton put it "historians of all stripes must necessarily engage with the decade's economics if they are to provide the necessary context for their research". ${ }^{7}$ It was in the 1970 s - partly thanks to the emergence of summitry - that political economy became part of "high politics": as Schmidt himself famously put it, "monetary policy is foreign policy".

Finally, and perhaps most importantly, one of the great challenges of the study of the 1970s lies in reaching the right balance between the various dimensions of European governance - that is its transnational, supranational and intergovernmental as-

6. R. BOYCE, The Great Interwar Crisis and the Collapse of Globalization, Palgrave, MacMillan, Basingstoke, 2009.

7. L. BLACK, H. PEMBERTON, Reassessing the seventies: the benighted decade, in: British Academy Review, November(2009), p.17. 
pects. It seems to me particularly problematic because, sometimes (like in the case of the landmark of the period, the EMS), the influence of purely non governmental actors (business, trade unions) is very tiny not to say inexistent. For the EMS, there was no such thing as the roundtable of industrialists of the Single European Act and we cannot invent it. At the same time the 1970s witnessed a true increase in the organisation and power of such transnational, non-governmental actors. Crucially, the 1970s witnessed the rise of multinational corporations and capital markets. The challenge and difficulty is to reach a balanced assessment of these influences. An explanation based exclusively on either transnational or supranational or intergovernmental approaches does not satisfactorily work. And it particularly does not work in the 1970s with the concomitant 1) rise of summitry, 2) rise of transnational nongovernmental actors, and 3) affirmation of supranational ones. It is their interaction which matters in understanding why a given policy outcome has been decided upon.

I do not think, however, that we need a brand new intellectual approach to do this. Quite the contrary, I would rather argue that we need to come back to some of the basics of the discipline of international history. The historiography is currently very Anglophone-centred and it would do no harm to bring in more the contributions of the Franco-Italian school of history of international relations. Many of the 'new' approaches brought to the niche of European integration history had actually been developed for quite a while elsewhere. In short, European integration historiography, while duly looking at the debates of other disciplines (not only political science, but also sociology, economics, anthropology), should also very simply look at international history debates and historiography. Breaking from the "state-centric approach" is absolutely fine and needed. ${ }^{8}$ Yet historians should not forget the history of their own discipline: breaking form the state-centric approach is not something new, and to understand this, we must look at the field of international history as such - and to place European integration history as one sub-field of it. Going beyond a mere diplomatic history was indeed at the heart of the emergence of the school of l'histoire des relations internationales in France and then Italy. The need for cooperation between historians and political scientists, sociologists, economists, anthropologists, has equally not been invented in the last decade. The École des Annales suggested and did it from the 1920s and 1930s onwards. ${ }^{9}$ And importantly for IPE, the original title of the publication was Annales d'histoire économique et sociale. Jean-Baptiste Duroselle, Pierre Renouvin and many others then brought it to what was then "diplomatic history", which as a consequence became "international history". René Girault and Robert Frank's Turbulente Europe et nouveaux mondes or Ennio Di Nolfo's Storia delle relazioni internazionali then bottle-fed generations of French and Italian

8. W. KAISER, B. LEUCHT, M. RASMUSSEN (eds.), The History of the European Union. Origins of a trans- and supranational polity, 1950-72, Routledge, London, 2009.

9. See for instance L. FEBVRE, Vivre l'histoire, Robert Laffont, Paris, 2009. 
historians. ${ }^{10}$ These are international history books which already took into account transnational phenomena and non governmental actors. The various volumes published by Éric Bussière and Sylvain Schirmann over the past decade, entitled Les milieux économiques et l'intégration européenne, also applied such a methodology. ${ }^{11}$ It would arguably be wise for future works on European integration history to engage first with the historical literature of this school of international history, and thus start reading more French and Italian.

\section{Potential new directions}

Some of the new directions I suggest below are just informed guesses, and of course largely influenced by my research interests and my own current work. For what they are worth, here are three big issues that I thought might be the focus of future research. The first area is certainly the widest but I think also the most important, and concerns the relationship between ideas and policy change. The 1970s were indeed the pivotal decade in the evolution of the postwar economic and monetary consensus. The late 1970s/early 1980s witnessed the apparition of two radical policy courses, with, to simplify, neo-liberalism on the one hand (implemented in the UK and the US under Margaret Thatcher and Ronald Reagan) and socialism on the other (in France under François Mitterrand). In order to understand how both developed we need very obviously to understand where they come from - and their roots date back from the 1970s and even late 1960s.

One of these areas of investigation, and one which seems to me considerably misunderstood and misrepresented, is monetarism. "Monetarism" has become a catchword synonym of "deregulation", "free market", "neo-liberalism" supported by Reagan and Thatcher. But monetarism originated as an academic economists' investigation into the causes of inflation in the late 1960s. It then moved on to some generalisations, some re-interpretation, but is certainly not as monolithic as is often suggested. Jeffrey Chwieroth has thus recently shown that the IMF's staff thinking about capital controls was not monolithic. ${ }^{12}$ It is fascinating to see the discussions of European central bankers (both in national, European and global settings) and how they react/interpret and consider applying (or not) these ideas. It would thus be crucial to try to trace the evolution of this thinking, how it was received in Western Europe by central bankers, economists, finance ministers, treasuries, ...- and applied (or

10. R. GIRAULT, R. FRANK, Turbulente Europe et nouveaux mondes, 1914-1941, Petite Bibliothèque Payot, Paris, 2004; P. RENOUVIN, J.-B. DUROSELLE, Introduction à l'histoire des relations internationales, Pocket, Paris, 2007; E. DI NOLFO, Storia delle relazioni internazionali, 1918-1999, Editori Laterza, Roma, 2000.

11. É. BUSSIÈRE, M. DUMOULIN, S. SCHIRMANN (eds.), Milieux économiques et intégration européenne au XXe siècle. La crise des années 1970, Peter Lang, Brussels, 2006.

12. J. CHWIEROTH, Capital ideas: The IMF and the rise of financial liberalization, Princeton University Press, Princeton, 2010. 
not). It is particularly crucial because the centrepiece of the 1970s, the EMS, does not fall into these clear-cut categories. As Schmidt used to say, a consequent monetarist would have opted out of the EMS - and a consequent Keynesian would have done just the same. ${ }^{13}$

Other theoretical discussions of academic economists are also important and should be kept in mind, like the so-called "holy trinity" (fixed exchange rates/circulation of capital/autonomy of monetary policy) set out by Robert Mundell in the 1960s, and still of Mundell (but extensively detailed afterwards by others) the "optimum currency area" debate. It is not only crucial to understand these debates per se, but also to see how they evolved and how they moved from academic economists to policy-makers. Just to take one example, it seems to me important to better detail the sequence of events going from Mundell's triangle of incompatibilities in the 1960s, to Tommaso Padoa Schioppa's thoughts as head of the DGII from 1979 to 1983, until the creation of the euro. How did these ideas circulate? Were all these steps consciously interconnected? Did the DGII recruit academic economists who had previously worked in the US? Did European central bankers read academic journals or were they simply influenced by informal discussions with academics? Or were they former academics themselves?

A final important issue is the question of how the various EEC policies of the period fit together. Social policy, regional policy, competition policy, etc. are so far largely studied in isolation. This is of course very useful because we know relatively little about them. But it would be important to see the wider picture, how they relate to each other. A good hint at this question was given by the so-called "concurrent studies" which ran in parallel to the EMS negotiations, and were meant to help the participation of the "less prosperous" EEC member states (Britain, Ireland and Italy). This was very interesting because it showed the interaction of economic policies (meant to improve economic convergence between member states) and monetary policy (a semi-fixed exchange rate system shared by the same member states). Was there, more generally, any conscious linkage between the two? It is fairly clear that the Commission was willing to find ways to replicate at the European level the mechanisms of fiscal/financial/regional redistribution which existed in other integrated economies. But how did it intend to do it? What was the opinion of the member states? Attempting to answer these various questions would certainly help having a better sense of the political economy of the decade - and certainly shed light on today's predicament.

Emmanuel Mourlon-Druol (University of Glasgow)

13. H. SCHMIDT, Die Deutschen und ihre Nachbarn, Siedler, Berlin, 1990, p.265. 


\section{Facing the Global South}

The European Community (EC) and Global South are both elusive entities in international history. The European Community and the Global South are in fact rarely, if at all, recognized as actors with some degree of autonomy in international relations after the Second World War. Here I would like to expand on some of the reasons why, increasingly so in the 1970 s, this two entities and their interaction are important in understanding both the evolution of the global economy and the role the EC had within it.

The simple consideration that the EC and the Global South emerged more or less at the same time should have raised more than one question about the nature of the link between the two. In fact there are at least two important links: both would hardly have existed without decolonization, and both have gained momentum and relevance some time in the middle of the 1950s. In the case of the Global South, although certainly the Cold War was instrumental in generating the need for a coalition able to promote peace against nuclear Mutually Assured Destruction, it is quite obvious that only the end of European colonial empires allowed for the possibility of autonomous action by newly independent countries in the international arena. On the other hand, in the case of European integration, the link with decolonization is possibly less straightforward but hardly less stringent. We now know that even well into the 1950s European colonial powers had no clear intention of renouncing the strategic importance of their empires from a cultural, political and even from an economic point of view. This is well demonstrated by the most recent historical literature that takes very seriously the effort to revive European colonial empires in the 1950s; an effort mainly undertaken by France and Great Britain and defined by scholars as "post-imperial reflex". ${ }^{14}$ The very same Jean Monnet recalled how Louis Armand one of the "three wise men" charged, after the failure of the European Defence Community in 1954, with re-launching a common European initiative through a joint atomic energy project - provocatively proposed the creation of a statue honouring Nasser as "the federator of Europe". ${ }^{15}$ Having dealt a mortal blow to the imperial dreams of France and the United Kingdom in 1956, the Egyptian leader had also cleared the path for a new French commitment in Europe.

The Global South has only recently attracted wide attention by historians. The term Global South has a more nuanced meaning than Third World, although here they will be used interchangeably. While in fact the origins of the term Third World is well-known, for it being used for the first time in 1954 to differentiate a group of "poor" countries from the industrialized Capitalist and Communist worlds; the term Global South is used even today to refer to all those countries and governments, but even social movements, that in one way or the other are opposed to or simply want

14. F. COOPER, Reconstructing Empire in British and French Africa, in: M. MAZOWER, J. REINISCH, D. FELDMAN (eds.), Post-War Reconstruction in Western Europe. International Perspectives, 1945-1949, Oxford University Press, Oxford, 2011.

15. J. MONNET, Mémoires, trans. Richard Mayne, London, Collins, 1978, p.422. 
to exert a greater influence on the management of globalization. The Global South has been defined by scholars such as Vijay Prashad as a political and cultural project potentially capable of generating a new form of internationalism in competition both with Communist and Liberal-democratic internationalism. ${ }^{16}$ This interpretation has been heavily criticized by Odd Arne Westad for being over-romantic because the story of the Third World, itself the product of European ideology and of the Cold War, should in fact be regarded as a story of errors to be avoided in the future. Westad argues that: "what is needed is a hard-nosed understanding of the Third World idea in order to avoid repeating its mistakes". ${ }^{17}$ Whatever the interpretation of the phenomenon, the most recent historiography on the Third World has confirmed that developing nations often struggled, both individually and collectively, to advance their own visions of modernization, more often than not characterized by high levels of State intervention and aspirations of fast-track industrialization, ${ }^{18}$ just as they fought to promote their own priorities in the realm of human rights and international law. ${ }^{19}$ Some historians have preferred to focus next to exclusively on the economic aspect of relations among the countries of the Global South taking into account the rise of "structuralism", eventually to become the driving ideological force of United Nations Conference for Trade and Development (UNCTAD) and of the creation of the G77 within it. This economic struggle of the Global South eventually peaked in the 1970s with the debate over a New International Economic Order to reform the Bretton Woods institutions created during WWII. ${ }^{20}$

Up to the beginning of the 1980s both historians and political scientists seemed to share a widespread confidence on the emerging role and the enduring relevance of the Global South. Hedley Bull and Adam Watson of British Committee on the Theory of International Politics, in the monumental The Expansion of International Society published in 1984, still considered the role of the Third World and its rebellion as crucial to adapting international institutions to the new international equilibrium. ${ }^{21}$ In fact the majority of historians that employ this definition now consider the cooperation within the Global South and its very same existence to have weakened -

16. V. PRASHAD, The Darker Nations. A Peoples History of the Third World, The New press, New York, 2008. See also: C.J. LEE (ed.), Making a World After Empire. The Bandung Moment and Its Political Afterlives, Ohio University Press, Athns, 2010.

17. O.A. WESTAD, The Project, in: London Review of Books, 2(2008).

18. D. ENGERAN, C. UNGER, Introduction: Towards a Global History of Modernization, in: Diplomatic History, 3(2009).

19. S.L. HOFFMANN, Genealogies of Human Rights, in: S.L. HOFFMANN (ed.), Human Rights in the Twentieth Century, Cambridge University Press, New York, 2011.

20. One of the best examples of such historiography is the biography of the founder of "structuralism", the Argentinean economist and first head of UNCTAD Raul Prebisch: E.J. DOSMAN, The Life and Times of Raul Prebisch, McGill-Queen's University Press, Montreal, 2009.

21. H. BULL, A. WATSON (eds.), The Expansion of an International Society, Clarendon Press, Oxford, 1984. 
possibly to the point of rendering the concept unacceptable for the later period - at the end of the 1970s. ${ }^{22}$

Historians of post-WWII international history have concentrated for a long time on the Cold War and on its impact on Europe as well as, more recently, on its role in shaping the conflicts and the outcomes in the Third World. There is nothing to be surprised if the same is true for the growing literature on the external dimension of the EC. This has prevailingly been focused on the study of transatlantic relations, on the pressure exercised by transatlantic elite networks, on the undeniable influence of Americanization and consumerism, or on the role of the EC within European Cold War diplomacy, for example during the negotiations for the Conference on Security and Cooperation in Europe (CSCE) ${ }^{23}$ In as a much as this literature on European integration has focused on relations with Third World countries, scholars have been mainly been attracted by the issue of development aid and of association agreements with Francophone and Anglophone countries, previously included within European colonial empires. More often than not researchers have concentrated on the technical details and on the procedures of the DG of the Commission in charge of development aid, on the different approaches and the mechanisms of national and European aid bureaucracy, and have described cooperation and development as a one-way process with influence and money moving from Brussels, or from one or the other different European capitals, to the less developed countries, mainly - but not exclusively - in Africa. $^{24}$

Probably the main reason why in very recent times there started to be a growing interest in the EC as part of a more complex and truly global web of international networks and of cultural and economic relations, derives from the changes in the perception and reality of the contemporary world. Issues such as the emergence of globalization and the questioning of its "dark side", the rise of a more multilateral world and the shrinking role of the US and of the Atlantic Community in cultural, political and economic terms confirmed by the recent passage from the G7 to the G20, are starting to redirect in many ways the attention from the West to the Rest. This present international environment has been conducive to reconsidering the importance of the Global South in its two "glorious decades" of the 1960s and 1970s as a phenomenon that might have influenced the European Community in its evolution as opposed to a coalition that has simply been influenced by former colonial empires or be the two superpowers. The question of the loss of empires and of its impact from the 1960s trough the 1970s has been reconsidered in different ways.

Gérard Bossuat has edited in 2006 a book that lists a convincing number of relevant aspects, ranging from trade to association agreements, in which the $\mathrm{EC}$ has been

22. The distinction among periodizations depends if the emphasis is centered on the cultural and political element of cooperation that certainly weakened with the failure of the Trilateral Conference in 1966, or on the economic aspect of cooperation which weakened with the second oil crisis in 1979 and with the war between two Third World and key oil-producing countries: Iran and Iraq.

23. Some of this issues in: W. KAISER, A. VARSORI (eds.), European Union History ..., op.cit.

24. A recent and useful study along this lines: E. CALANDRI (ed.), Il primato sfuggente. L'Europa e l'intervento per lo sviluppo (1957-2007), FrancoAngeli, Milano, 2009. 
active in facing the emerging Third World. ${ }^{25}$ My own study Dopo gli imperi (After Empires) has focused more on the interaction between the Common Market and the emergence of developing countries as autonomous economic but also political actors in the international arena. ${ }^{26}$ I consider the 1973 "oil shock" as the high point of this phase of "discovery of interdependence". Even at the very end of the 1960s some of the most acute political scientists had made it quite clear that the future of the EC after 1968, with the profound turmoil generated by students and workers revolts at home and Third World radicalization abroad, could not but be profoundly linked with some kind of new relationship established with former colonies: "European colonialism and decolonization-especially that of Britain and France-have left many legacies which provide opportunities for continuing ties today and help or hinder new definitions, declaratory and operational, of purposes, policies, and procedures. The future of Europe and the future of the Third World are two profoundly open and complex sets of possibilities which will, in some manner, undoubtedly interact. Any substantial political rearrangements in Europe will, it is most likely, be inaugurated and practiced without any substantial influence from the Third World. If greater European unity is accomplished, then Europe could become a great benefactor to some, or most, of the countries of the Third World. Europe and the Third World are, in many important senses, co-members of one world". ${ }^{27}$

Another set of issues, deeply linked to the processes occurring in the Global South, is represented by non-European immigration and its impact both on Western European culture and on its economy and society. An example of the growing perception of the importance of the question of immigration for the formation of European societies is the widely read study of Harmut Kaelble on the social history of Western Europe. In its first edition (1990) it did not even refer to immigration; in its second edition (2007) immigration become one of the most important elements shaping European society. ${ }^{28}$ Non-European immigration and its study will be crucial in understanding the evolution of European economy in the 1970s: for example how much of the strong competitiveness of the German economy even after the 1973 oil shock was due to the possibility of containing salaries and wage demands from the less integrated and organized working class of Turkish origins? A related and potentially innovative field of study concerns the formation of "post-colonial" European identities and is lead by historians of colonial empires. These scholars are increasingly been intrigued by the way in which the loss of colonies contributed to the shaping of the new national and "European" identities. Todd Shepard, in a seminal study published in 2006, wrote on the French citizenship being identified with the Hexagon and continental Europe only after that Algerians had definitively been considered

25. G. BOSSUAT, L'Europe et la mondialisation, Ed. Soleb, Paris, 2006.

26. G. GARAVINI, Dopo gli imperi. L'integrazione europea nello scontro Nord-Sud, Le Monnier, Firenze, 2009.

27. P. LYON, Europe and the Third World, in: Annals of the American Academy of Political and Social Science, 386(1969).

28. H. KAELBLE, Sozialgeschichte Europas. 1945 bis zur Gegenwart, Beck, Munich, 2007. 
Africans with no right to French citizenship in $1962 .{ }^{29}$ Similar studies are currently being undertaken for other countries.

Even broader and more long-term questions arise from the debate and analysis of the question of loss of empires and the rise of new actors in the Third World. Among such broader issues is the impact of the non-European world on the colonial powers in a variety of ways on the longue durée, not exclusively in the 1960s and 1970s. This approach could help placing the EC and its outcomes in the longer process of formation and dissolution of European empires. An example of this new trend is for example evident in the conference organized in Freiburg (May 2010) with the theme: Making Europe. The Global Origins of the Old World. ${ }^{30}$ In the words of the organizers, this conference outspokenly had the purpose of challenging a "Europeanised version of the history of Europe":

"Making Europe, in contrast, will demonstrate, for example, that large swaths of Europe were much more connected to extra-European spaces than to 'Europe' as such; that important European societies, such as in Britain, were at least as much defined by networks encompassing Asian, African and American territories than by their 'European' connections; that the famed political culture of European states was heavily influenced by imperialism, that Europe's economic development, its 'great divergence', cannot even be begun to be understood without reference to connections to the rest of the world; and that European political development in the twentieth century can only be made sense of by putting both decolonization and the Cold War superpowers at the centre of our narrative".

Historians of the colonial empires will necessarily have to engage in the future not only with the question of decolonization but also with the immediate aftermath of the decolonization process. John Darwin has argued that: "far from heralding a 'world of nations', decolonization's unexpected course seemed to have set the scene for new kinds of empire". ${ }^{31}$ The prevailing narrative of the historians of empires, that decolonization transformed European empires into an American empire, or that it only gave birth to another form of imperialism this time exercised through free trade and indirect economic and political control, is not entirely convincing. This narrative will have to take into account the agency of former colonies and the pressures rising from their newly acquired political and economic role.

If these are all important tendencies in historiography, the broader issue than will be difficult to be avoided by diplomatic historians in the future is that the evolution of European integration cannot be explained if not in parallel with the pressures exercised upon it by the non-European world, and particularly by former colonies. By the beginning of the 1980s the Global South as a cooperative international actor was no more and globalization increased international competition rather than - or together with - international cooperation among countries of the South. This does not

29. T. SHEPARD, The Invention of Decolonization. The Algerian War and the Remaking of France, Cornell University Press, Ithaca, 2006. Although the same kind approach had been taken previously even from the 1970s in many of the works of Henri Wesseling on The Netherlands.

30. http://www.frias.uni-freiburg.de/history/veranstaltungen/KonfBeckert.

31. J. DARWIN, After Tamerlane. The Rise and Fall of Global Empires 1400-2000, Penguin, London, 2008, pp.476-477. 
mean that European integration can then be explained only by its links with the other side of the Atlantic. For example: even the very strong efforts to revive integration through the Single Market Project, heavily sponsored by the European Commission in the second half of the 1980s also by promoting a search for the historical roots of the integration process (which incidentally brought to the creation of the Liaison Group of Historians of the European Union), cannot be explained without taking into account the tougher economic environment and the competition arising from the newly industrialized countries, specially in Asia.

All the above does not mean that we will have to indulge in a narrative where there is no place for conflict both in cultural and political terms: the "multicultural" narrative of Brussels or of mainstream media and intellectuals for whom Western European countries have lost empires, become hubs of immigration, witnessed the rise of economic interdependence, and this process has all happened peacefully, finally contributing to the rise of a model European "civilian power". ${ }^{32}$ All to the contrary, I think that the story of the long decade of the 1970s, from 1968 to the beginning of the 1980s was one of an effort of cooperation between Western European countries - including the EC - with the still cooperating Global South. At the same time the history of the last 30 years is one prevailingly defined by a reassuring public speech but also by profound tensions both in economic and cultural terms with the new economic and political actors formerly participating to the Third World project, by an inward-looking effort concentrated on a Europe-wide Single Market, and possibly by a revival of the ambition to link European identity to its supposedly Christian origins. $^{33}$

Giuliano Garavini (Research Fellow, University of Padua)

\section{Towards an International History of European Integration: The European Communities and the United States during the 1970s}

We can hardly analyze the history of the relations of the European Communities (EC) with the United States during the 1970s without linking it to the wider context. Momentous shifts in the global order shaped the course of events. The United States entered in a period of détente with the Soviet Union. The 1972 Anti-Ballistic Missile Treaty and the 1973 Agreement on the Prevention of Nuclear War were major breakthroughs. By creating a new sense of security, superpower détente opened a field of independent diplomatic activity for EC countries. It also raised concerns about USSoviet collusion. As such, it encouraged Western European decision-makers to think that their interests might differ from US policy. World economic transformations,

32. J. RIFKIN, Europe's Dream. How Europe's Vision of the Future is Quietly Eclypsing the American Dream, Penguin, London, 2004.

33. C. CALDWELL, Reflections on the Revolutions in Europe. Immigration, Islam and the West, Doubleday, New York, 2009. 
moreover, sowed transatlantic division. A widening US balance-of-payments deficit had intensified US domestic pressure for troop redeployment. The 1971-1973 collapse of Bretton Woods spurred transatlantic disagreements on the world monetary order. Last but not least, growing European prosperity and a declining US trade balance fuelled US opposition to EC protectionism.

\section{State of the Art}

New research pays due credit to the links between EC-US relations and the wider international context during the 1970s. The newly created European Political Cooperation (EPC) offers a lens through which to view the connections with the Cold War. Daniel Möckli and I, among others, have stressed the link between EPC's dynamism in 1973-1974 and US-Soviet relations. ${ }^{34}$ Mindful of the risk (more imaginary than real) of a US-Soviet "condominium", the EC Nine responded to America's "Year of Europe" initiative by asserting the distinctiveness of a united Europe. The US-Soviet dialogue/contest over the Yom Kippur War was an important factor behind their November 1973 Declaration on the Middle East, the first public statement by EC countries on a major international issue. The French and the British governments in particular pushed for it because they resented their exclusion from the talks over the Arab-Israeli conflict, both during and in the aftermath of the war. ${ }^{35}$ Sara Tavani's work points to similar connections in the early 1980s. ${ }^{36}$ Despite the Soviet invasion of Afghanistan, the EC Ten remained wedded to détente unlike the US government. With the rise of the Solidarity mass movement in Poland, they developed a distinctive approach towards the Polish regime. They made initial gestures of good will to support its reformist attempts. After the 1981 introduction of Martial Law, they applied joint economic sanctions - albeit milder ones than what the US government wanted.

Recent work on Greece highlights the importance of the Cold War context for the southward enlargement of the EC. Antonio Varsori shows that broader geopolitical concerns were decisive in the EC Nine's decision in 1976 to open accession negotiations with the new democratic government of Constantinos Karamanlis. ${ }^{37}$ Despite widespread concerns about Greece's economic backwardness, EC states calculated that EC membership was essential to achieve domestic stability and anchor the coun-

34. D. MÖCKLI, European Foreign Policy During the Cold War: Heath, Brandt, Pompidou and the Dream of Political Unity, I.B. Tauris, London, 2009; A.É. GFELLER, Building a European Identity: France, the United States, and the Oil Shock, 1973-1974, Berghahn Books, New York, forthcoming.

35. A.É. GFELLER, A European Voice in the Arab World: France, the Superpowers and the Middle East, 1970-1974, in: Cold War History, 4 (2011).

36. S. TAVANI, CFSP Origins and European Détente: A Common European Stance on the Polish Crisis of 1980-1981, (paper presented at the Sixth History of European Integration Research Society (HEIRS) Colloquium, University of Reading, UK, 2010).

37. M. DEL PERO, V. GAVIN, F. GUIRAO, A. VARSORI, Democrazie. L'Europa meridionale e la fine delle dittature, Le Monnier, Firenze, 2010. 
try firmly to the West. Cold War-related considerations also facilitated the Greek accession by reducing US apprehension about diminished influence in Southern Europe. Eirini Karamouzi points to a cooperative division of labour between the United States and the EC Nine. ${ }^{38}$ Karamanlis's government loosened its ties with the US government due to US support of the former military dictatorship and possible US involvement in the Turkish attack on Cyprus in 1974. In this context, the Ford administration, Karamouzi argues, supported EC membership as a way to strengthen its stabilizing role in the region.

Historians have also started to probe the links between EC-US relations and international economic developments. I will not discuss the literature on European monetary reforms; this topic is addressed by Emmanuel Mourlon-Druol. Trade provides another fitting example. In 1957, US President Dwight Eisenhower had defended the Rome Treaty against opposition from Australia, Britain, Canada, and New Zealand. In 1973, by contrast, the Nixon administration requested financial compensation under the General Agreement on Tariffs and Trade (GATT) for the EC's enlargement to Britain, Ireland, and Denmark: despite lower tariffs on manufactured goods, EC membership implied a higher level of protection. How did this shift crystallize? The existing scholarship underscores the antagonistic stance of several governmental divisions: the US Department of the Treasury, the Department of Commerce, and the Department of Agriculture. ${ }^{39}$ It also points to the declining influence of the State Department's "Europeanists" in the Nixon administration. ${ }^{40}$ Whether this shift in the US stance had any implications for the accession agreement, however, remains a matter for further investigation.

\section{Methodological Challenges}

The history of EC-US relations provides opportunities for linking European integration to other subfields of international history; it also raises methodological challenges. I shall mention two here. First, the EC and EPC were only one of the forums in which the US government interacted with Western European countries. Bilateral relations remained alive and well. There was also a plethora of Western organizations: the North Atlantic Treaty Organization (NATO), the GATT, the International Mon-

38. E. KARAMOUZI, Telling the Whole Story: America, the EEC and Greece 1974-1976, in: A. VARSORI, G. MIGANI (ed.), Europe in the International Arena During the 1970s: Entering a Different World, Peter Lang, Brussels, 2011.

39. L. COPPOLARO, The United States and EEC Enlargement (1969-1973): Reaffirming the Atlantic Framework, in: VAN DER HARST (ed.), Beyond the Customs Union: The European Community's Quest for Deepening, Widening and Completion, 1969-1975, Bruylant, Brussels, 2007. See also L. NICHTER, Richard Nixon and Europe: Confrontation and Cooperation, 1969-1974, Ph.D. thesis, Bowling Green State University, 2008.

40. K. WEISBRODE, The Atlantic Century: Four Generations of Extraordinary Diplomats who Forged America's Vital Alliance with Europe, Da Capo Press, Cambridge Mass., pp.209-219. 
etary Fund, the World Bank, and the Organization for Economic Cooperation and Development. Further institutions were established in the 1970s to reduce Cold War tensions (the Conference on Security and Cooperation in Europe) and to address global economic challenges (the Group of Five, which was subsequently enlarged to the Group of Seven, that is, Britain, Canada, France, Italy, Japan, the United States, and West Germany). These forums were interconnected. What happened in one arena had implications for events unfolding in another, and conversely. Still, it is important to distinguish between them. Like historical actors themselves, historians are often guilty of semantic indeterminacy. Rather than specify which countries/organization they designate, they tend to use the phrase "the Europeans" as a convenient shortcut. Such indeterminacy is especially problematic since the historical use of this term was not value-neutral. US officials, for one, often used the phrases "the Europeans" and "the Allies" as interchangeable categories, failing to refer to the EC/EC states per se, because they did not recognize the existence of a separate European entity.

These overlapping sets of relations imply that EC-US relations were only one aspect of a complex history. There are two competing narratives for the history of transatlantic relations after World War II: the paradigm of the "empire by invitation", and the story of a gradual estrangement between the United States and Western Europe after a brief period of postwar cooperation. The term "empire by invitation" was coined by Norwegian historian Geir Lundestad. ${ }^{41}$ Yet Lundestad himself presents this empire as a temporary phenomenon, which lasted about thirty years. Beginning with the Carter administration, he claims, much of "the urge to involve the Americans that had characterized the early decades of the Atlantic relationship" vanished ${ }^{42}$ Historians should engage explicitly with this debate when discussing EC-US relations. Their overall vision of transatlantic relations is bound to shape their analysis of specific events. This does not mean taking side. It is also possible to opt for a middle ground. In a recent edited volume, Matthias Schulz and Thomas Schwartz tell a cyclical tale: "these relations moved in cycles of cooperation and conflict". ${ }^{43}$ This is a somewhat messier framework, but it seems better suited for describing the ebbs and flows of the transatlantic relationship since World War II.

\section{Avenues for Further Research}

There is still much that we could and should learn about EC-US relations during the 1970s. Much of the existing scholarship is in a classic diplomatic history vein. It gives

41. G. LUNDESTAD, Empire by Invitation? The United States and Western Europe, 1945-1952, in: Journal of Peace Research, 3(1986).

42. G. LUNDESTAD, The United States and Western Europe since 1945: From "Empire" by Invitation to Transatlantic Drift, Oxford University Press, Oxford/New York, 2003, p.223.

43. M. SCHULTZ, T.A. SCHWARTZ, The Superpower and the Union in the Making: U.S.-European Relations, 1969-1980, in: M. SCHULTZ, T.A. SCHWARTZ (ed.), The Strained Alliance: U.S.European Relations from Nixon to Carter, Cambridge University Press, New York, 2009, p.355. 
pride of place to prominent individuals-President/Prime Minister and Foreign Minister/Secretary of State. It also focuses on a limited number of countries, namely, Britain, France, the United States, and West Germany. Personalities were certainly influential, but even under a presidential regime such as France's Fifth Republic a wider range of actors shaped foreign policy. ${ }^{44}$ Future research should place greater emphasis on diplomatic discussions beyond Richard Nixon, Henri Kissinger, Willy Brandt, Edward Heath, Georges Pompidou and the like. It should also explore policymaking within the EC beyond the big three (Britain, France, and West Germany). Studies on the Netherlands' and Italy's oil policy have begun to do so, but only tangentially. ${ }^{45}$

Existing studies on transatlantic relations during the 1970s deal essentially with the first half of the decade. Joe Renouard and Nathan Vigil's study of the Carter administration's European policy relies mostly on publicly available materials. ${ }^{46}$ As archival materials become available for the second half of the 1970s, historians should study the evolution of the US stance on European integration. The scholarship on the Nixon years points to a policy shift. Lundestad emphasizes the heightened sense of economic competition among US political actors and a new belief that a multi-centered, confederal structure would better serve US policy objectives than a single, supranational European body. ${ }^{47}$ In his doctoral thesis, Luke Nichter argues that the Nixon administration was the first US government to conclude that further integration was not in its best interest, ceasing to support either widening or deepening. ${ }^{48} \mathrm{Schulz}$ and Schwartz stress the new "coolness" of the US government towards European integration, casting it as "one of the most distinctive changes in US policy during this era". ${ }^{49}$ US concerns about European integration were not entirely new. ${ }^{50}$ The belligerent tone of the Nixon administration, however, was unprecedented. Was this a temporary shift or a more lasting development? How did US policy evolve during the rest of the decade? Further research is needed to answer these questions.

We should also investigate EPC's history after 1974 and probe the links between its dynamism, or lack thereof, and transatlantic relations. The scholarship on EPC's early days suggests that there were conflicting dynamics. Transatlantic antagonisms could foster European political unity contra the United States. This was true of the EC Nine's response to the Year of Europe and of their Declaration on the Middle East. But the transatlantic connection could also work the opposite way. At the 1974 Washington Energy Conference, France parted way with its EC partners over US

44. See A.É. GFELLER, Building a European Identity ..., op.cit.

45. D. HELlEMA, C. WIEBES, T. WHITE, The Netherlands and the Oil Crisis: Business as Usual, University of Chicago Press, Chicago, 2004; S. LABBATE, Il governo dell'energia. L'Italia dal petrolio al nucleare (1945-1975), Le Monnier, Firenze, 2010.

46. J. RENOUARD, D.N. VIGIL, The Quest for Leadership in a Time of Peace: Jimmy Carter and Western Europe, 1977-1981, in: M. SCHULTZ, T.A. SCHWARTZ (ed.), op.cit., pp.321-324.

47. G. Lundestad, The United States and Western Europe ..., op.cit., pp.177-182.

48. L. NICHTER, op.cit.

49. M. SCHULTZ, T.A. SCHWARTZ, "The Superpower and the Union ..., op.cit., p.362.

50. See V. HEYDE, De l'esprit de la Résistance jusqu'à l'idée de l'Europe, Peter Lang, Brussels, 2010 . 
international energy policy. Did such contradictory effects characterize EPC's further development? In 1980-1981, the EC Ten gave a new lease of life to EPC. They issued statements on the Arab-Israeli conflict, the Iran hostage crisis, Afghanistan, and Poland. They also adopted joint sanctions on Poland and Iran. By calling for an overall Middle East peace settlement and pleading for continued détente, they took a different stance from the United States. Did differences, and even antagonisms, with the US government spur this revival of EPC? Does US policy explain EPC's lower profile after 1974 and 1981, respectively? These questions highlight the need for further research.

The Southward enlargement of the EC and its transatlantic implications are another topic worthy of investigation. Did the Carter administration support Portugal's and Spain's 1977 application for EC membership in order to anchor these newly democratized countries to the West? Did the US government see EC membership as interfering with its policy objectives, that is, bringing Spain into NATO and keeping access to military bases in the Iberian Peninsula? The traditional interpretation stressed US misgivings about EC accession. More recent work has challenged this view. ${ }^{51} \mathrm{We}$ could still benefit from more research on the interconnections between the transatlantic relationship and the EC's third enlargement.

In addition, there should be further work on EC-US trade relations. Disagreements abounded in the early 1970s. The tariff implications of the 1973 enlargement were only one of many contentious issues. There were also the reverse trade preferences (granted by former colonies to EC countries), the Common Agricultural Policy, the scope of a new round of trade liberalization, and the EC's preferential trade agreements (with Israel, Spain, and European Free Trade Association countries). For all their differences, EC states and the United States reached agreement on launching a new GATT round in Tokyo in September 1974. By 1979, the Tokyo Round had come to a successful close; participants endorsed a series of tariff reductions and a Code on Subsidies and Countervailing Duties. How did EC-US relations evolve in this context? Was conflict, cooperation or a mix of both the dominant mode? What was the impact of the rise of new economic players like Japan? These questions are awaiting answers.

More broadly, historians should analyze the interplay between EC-US relations and the United States' interactions with Western European countries in other forums. How did these manifold conversations relate to one another? Did these multiple forums and patterns of cooperation allow EC countries to further their interests and European integration? How did officials on both sides of the Atlantic analyze the links between European integration and NATO? Did they point to a zero-sum game or to mutually reinforcing processes? We clearly need more research to tell how this complex story unfolded.

51. See for example Á. VINAS, En las garras del águila. Los pactos con Estados Unidos de Franco a Felipe González (1945-1995), Crítica, Barcelona, 2003. 
Future research, moreover, should move beyond the state-centered focus of the existing scholarship to encompass a wider range of actors. One possible approach would combine international, political and cultural history and investigate the debate over global interdependence in the 1970s. The concept of interdependence became an increasingly popular construct in US political circles and academia during the 1970s. Harvard Professors Robert Keohane and Joseph Nye defined "complex interdependence" as an ideal type. Its main characteristics were numerous channels of communication, a lack of hierarchy between negotiation topics, and the reduced usability of force. ${ }^{52}$ Keohane and Nye's argument implied that international interdependence reduced the ability of the superpowers to influence outcomes based on sheer military superiority. How did the discussions evolve on both sides of the Atlantic? Did political, economic and intellectual actors in EC countries view interdependence as a source of weakness or strength for medium-size European powers and a united Europe? A second, related approach would focus on the practical implications of the debate. How did business leaders in EC countries and the United States assess the situation? Which strategies did they apply, notably in the EC-US context? These research topics are important given the prominence of economic networks, notably the European Roundtable of Industrialists, in European integration in the early 1980s.

All in all, future research should situate the history of EC-US relations during the 1970s in the context of an evolving transatlantic relationship and a shifting geopolitical and economic order. Only so will we gain a better understanding of the significance of the US component of the EC's external dimension during this decade.

Aurélie Élisa Gfeller (Robert Schuman Centre for Advanced Studies)

\section{"Looking Eastward"}

The dramatic changes in the international system over the last twenty years call the EU to actively contribute to international security and the shaping of a new political and economic order, starting with Europe itself. In the post-Cold War system, the redefinition of equilibrium in the Continent has been of immediate concern, and EU's relations with its neighbouring East, i.e. Russia and other former USSR countries, are still one of the key issues in the political and scholarly debate on international relations. With the collapse of the bipolar system, in fact, the newborn European Union proved an irresistible magnet for former allies of the Soviet Union, which all applied for membership. Their becoming part of the EU affects the international role of the latter in two intertwined ways. On the one hand, to agree on a common foreign policy à 27 , and on the very mechanism to elaborate it, proves even more difficult.

52. R.O. KEOHANE, J.S. NYE, Power and Interdependence: World Politics in Transition, $3^{\text {rd }}$ ed., Longman, New York, 2001; J.S. NYE, Independence and Interdependence, in: Foreign Policy, 22(1976). 
On the other hand, the interests and sensibilities of these countries make relations with Russia more delicate to handle.

Over the decades, research on this topic has been led by political scientists and jurists with expertise in international and/or EC law. International history scholars, on the contrary, have been slow to devote attention to the EC/EU as an international actor, and particularly reluctant to deal with the specific case of its relations with the Soviet bloc. Still, the necessity and feasibility of a Europe speaking with one voice came to dominate the scholarly and the political debate since the early 1970s, when the EC started to be more active and self-assertive in many areas, and when important institutional changes began to this end. Moreover, a preliminary historical analysis shows that dynamics and issues of current EU-Russia relations, e.g. human rights, co-operation in the fields of energy, security, and environment, all emerged in the 1970s. As well, the pattern of EU's enlargement eastwards had its origins in the relations between the EC and Central and Eastern European countries in the previous decades. By placing recent developments in a longer perspective historical research would thus significantly contribute to a better understanding of present-day Europe. ${ }^{53}$

In accomplishing this task, historians of European integration would largely benefit from linking with Cold War history, for the bipolar structure significantly affected the relations between the $\mathrm{EC}$ and the communist countries all along the Cold War years. Reversing the link, Cold War historians should take into higher consideration the external dimension of the integration process and EC's international role.

\section{State of the art}

In the last decade, the scholarly debate on the Cold War has moved beyond superpowers' policy and relationship to focus on the role of small and medium powers in the 1970s and early 1980s, also prompted by the release of primary sources in many archives. Recent studies in the field recognise the 1970 s as a period marking a profound discontinuity in the political and economic international system..$^{54}$ In particular, it is evident that the consolidated geopolitical and ideological bipolar equilibrium began to be eroded, and that small and medium powers enjoyed greater autonomy. In this context, Western European détente involving the East in financial, commercial and cultural links is now acknowledged among the crucial factors in determining the end of the Cold War, and explaining the pace of the fall of communism in Euro-

53. This contribution results from my research work as Jean Monnet Fellow 2009-2010 at RSCAS, EUI.

54. O.A. WESTAD (ed.), Reviewing the Cold War. Approaches, Interpretations and Theories, Frank Cass, London, 2000; F. KNIPPING, M. SCHÖNWALD (eds.), Aufbruch zum Europa der Zweiten Generation. Die europäische Einigung, 1969-1984, WVT, Trier, 2004; A. VARSORI. (ed.), Alle origini del presente. L'Europa occidentale nella crisi degli anni Settanta, Franco Angeli, Milano, 2007. 
pe. ${ }^{55}$ So is the CSCE process, in which EC member states played a leading role in turning European international politics to a new kind of thinking. ${ }^{56}$ The EC too is recognised as a strong pole of attraction vis-à-vis the disastrous socialist experiment. ${ }^{57}$ Nonetheless, the emphasis to date has been bilateral and transatlantic rather than multilateral and pan-European, and the active role of the EC as such is still largely overlooked.

On its part, recent European integration historiography devotes more attention to the external dimension of the process and to the international role of the EC, linking European integration dynamics to the broader history of international relations. In this new research field, however, EC's relations with the Soviet bloc countries remain largely unexplored. To date, there are a few remarkable attempts to fill the gap. The volume edited by Piers Ludlow, European integration and the Cold War: OstpolitikWestpolitik, 1965-1973, brings evidence of the way in which the East-West conflict and the emergence of organised co-operation in Europe became entangled with one another in the member states' foreign policy. Moreover, Ludlow's own chapter brings the EC as such under scrutiny, debating the general assumption of a Community insulated from Cold War dynamics. ${ }^{58}$ Yamamoto successfully linked détente and integration in his article on EC response to the Soviet proposal for EC/Comecon relations in the early 1970s ${ }^{59}$ However, his analysis is focused on French, British and West German governments' approaches, identifies the EC with the Council of Foreign Ministers, and completely ignores the Commission. Making use of the vast amount of available EC primary sources, one finds that Soviet representatives approached the Commission first, and repeatedly since 1972, and that the supranational institution actively contributed to shaping EC response to Comecon. ${ }^{60}$

55. See F. BOZO et al. (eds.), Europe and the End of the Cold War. A Reappraisal, Routledge, LondonNew York, 2008; F. ROMERO, Storia della guerra fredda, Einaudi, Torino, 2009. P. VILLAUME, O.A. WESTAD (eds.), Perforating the Iron Curtain: European Détente, Transatlantic Relations, and the Cold War, 1965-1985, Museum Tusculanum, Copenhagen, 2010. M. LEFFLER, O. WESTAD (eds.), Cambridge History of the Cold War, Cambridge University Press, Cambridge, 2010, vol. II (see in particular the chapters by J. HANHIMÄKI, Détente in Europe, 1969-1975, N.P. LUDLOW, European integration and the Cold War, and J. YOUNG, Western Europe and the end of the Cold War, 1979-1989).

56. See D. THOMAS, Human Rights Ideas, the Demise of Communism, and the End of the Cold War, in: Journal of Cold War Studies, 2(2005), pp.110-141. A. WENGER, V. MASTNY, C. NUENDLIST (eds.), Origins of the European Security System: The Helsinki Process Revisited, 1965-75, Routledge, London-New York, 2009. M. LEFFLER, O. WESTAD (eds.), Cambridge History of the Cold War, Cambridge University Press, Cambridge, 2010, vol. III (see in particular the chapters by A. Robert, An 'incredibly swift transition': reflections on the end of the Cold War, and $\mathrm{R}$. Foot, The Cold War and human rights).

57. F. ROMERO, op.cit.

58. N.P. LUDLOW, European integration and the Cold War: Ostpolitik-Westpolitik, 1965-1973, Routledge, London-New York, 2007.

59. T. YAMAMOTO, Detente or Integration? EC Response to Soviet Policy Change towards the Common Market, 1970-75, in: Cold War History, 1(2007), pp.75-94.

60. A. ROMANO, Behind closed doors. Contacts between EEC and CMEA in the early 1970s, in: C. MENEGUZZI (ed.), The Helsinki Process. A Historical Reappraisal, CEDAM, Padova, 2005. 
Focusing on the multilateral and pan-European level, my book analyses the attempts of the EC-Nine to shape and promote a co-ordinated "European détente" on the occasion of the Helsinki CSCE. Not only does it demonstrate that EPC came to live and instantly flourished due to East-West dialogue, but also it brings into the argument the role and interests of the $\mathrm{EC}$ as such, and points to the question of gaining recognition from the Soviet bloc countries as one of the driving forces behind Western European collective action. ${ }^{61}$

The action of the Nine at Helsinki is also the one major success story Möckli reports in his thorough analysis on France, Britain, and West Germany and the emergence of EPC within the broader context of early 1970s Cold War intra-European and transatlantic relations. ${ }^{62}$ Moreover, while arguing that by 1974 this brief moment of concord had vanished and policy successes became rare, Möckli recognises the CSCE as the notable exception. In fact, my works moving beyond the early 1970s bring evidence of Western European collective CSCE action up into the 1980s. Furthermore, I point to a broader EC "Eastern policy", in which CSCE features along EC's intensifying bilateral relations with Eastern states. Most Soviet bloc countries informally approached the Commission to conclude bilateral dealings, and negotiations between the $\mathrm{EC}$ and Comecon went public. ${ }^{63}$ These contacts, together with the involvement of the Commission in several EPC working groups, made the EC institutions increasingly acknowledge East-West dynamics, appreciate the national political and economic realities of the Eastern countries, and shape EC policy and actions more accurately.

The above-mentioned scholarship has demonstrated the fruitfulness of historical analysis linking European integration and Cold War. It has convincingly argued that in the first half of the 1970s the flourishing of détente between the superpowers as well as between European states provided the ideal framework for asserting a "Europe speaking with a single voice". It has also shown that EPC turned out to be particularly successful at the Helsinki CSCE, and that the EC as such became actively involved in East-West relations. From the mid-1970s to the Gorbachev era the return of Cold War-like tensions between the superpowers narrowed EC-Nine's room for manoeuvre. Yet, recent works show that détente became a permanent task of EPC, and that EC-Soviet bloc relations grew more intense and diversified. Research on the next chapter of this story is badly needed, and moving into the long 1970s perspective seems particularly promising for studies connecting the two historical sub-fields.

\footnotetext{
61. A. ROMANO, From Détente in Europe to European Détente. How the West Shaped the Helsinki CSCE, Peter Lang, Brussels, 2009.

62. D. MÖCKLI, op.cit.

63. See A. ROMANO, The European Community and the Belgrade CSCE, in: V. BILANDZIC, M. KASANOVIC (eds.), From Helsinki to Belgrade, OSCE Mission to Serbia and Žikić Fond, Belgrad, 2008; A. ROMANO, La Comunità europea e il blocco sovietico negli anni Settanta, in: A. BITUMI et al. (eds.), La Comunità europea e le relazioni esterne 1957-1992, Clueb, Forlì, 2008; A. ROMANO, Western Europe, the US and the Madrid CSCE Follow-Up Meeting: Common Front, Different Strategies, in: K. PATEL, K. WEISBRODE, Europe and America in the 1980s: Old Barriers, New Openings, forthcoming.
} 
Research in this field moving its first steps, methodological issues are to be assessed and the research agenda is open to definition. I hereby suggest some directions, which are largely influenced by my own experience, interests, and agenda.

\section{Problems and methodological issues}

The "long 1970s" suggests the opportunity to define the period of analysis according to criteria more sophisticated than the simple time span of a decade. As for EC's relations with the East, I would propose the long 1970s as beginning in December 1969 - taking the EC Summit of The Hague as starting point - and ending in 1983 with the conclusion of the Madrid CSCE follow-up meeting. If we consider European détente, and the continuity in EPC machinery to deal with it, this choice proves consistent. As Prof. Wilfried Loth argued during workshop discussion, 1983

"is also plausible because the so-called Second Cold War ended just in this year. It was in early 1984, more than one year before Mikhail Gorbachev came into power, that Ronald Reagan started his charming offensive towards Moscow, genuinely aiming to improve relations and reduce the level of armaments".

In approaching research in this field, historians should free their minds from some narrative habits. First, the "East" or "Soviet bloc" is too often referred to as a single entity, almost coincident with the USSR, while differences among communist states were impressive as for political and economic rationales, interests and actions, especially when it came to relations with the EC. Second, scholars should get rid of the idea of "lost opportunities". Kissinger-attributed remark "Whom do I call if I want to speak to Europe?" still echoes in the public and academic discourse, especially of political scientists. Historians should refuse presupposition that only a supranational foreign policy might produce results.

This is linked to the problem of defining the EC actor whilst appreciating its complexities. I have heretofore referred to EC's relations with the East for reasons of convenience. Indeed, relations with the East involved both the EC as such and EPC, the latter being intended as collective action by the nine governments. Research may well focus on either of two, consider the two in parallel, or propose the definition of a hybrid entity comprising the two. The latter is usually the case when scholars refer to "EC-Nine". The choice is directly linked with the specific object of research. However, it is worth reminding that the borders between EC competence, EPC domains, and national prerogative is everything but rigid. First, the European integration itself is a process, and competence in specific areas may - and did in 1970s - shift from states to the EC. Second, the possible fields of co-operation with the communist countries required a combined EC/member states' action in case of shared competence. Third, the highly political character of relations with the East necessitated EC member states' diplomatic action even when the EC had exclusive competence. Finally, although foreign and security policies remained entirely within the scope of 
national governments and were dealt with via intergovernmental cooperation, their touching upon the integration process, actual and potential, increasingly required involvement of the EC Commission in discussions and decision making.

The hybrid EC polity gets further complex in the mid-1970s with the creation of the European Council. Its role is still overlooked although it represents one of the most interesting innovations within the integration process. I encourage scholars to take it into full consideration when analysing EC's relations with the East, for it is hard to imagine that the highest political authorities of the member states completely neglected issues such as East-West conflict and the international role of the EC.

EC Council, EPC, and European Council: no doubt the role of the member states remains crucial within the European polity. However, research should move beyond purely national approaches and examine, in a transnational perspective, the ways in which mutual influences, common European ideas and standards, EC legacy, and path-dependencies deriving from previous decisions played a role in decision making. Ideological commitments, the willingness to avoid isolation, the socialisation among national officials and politicians all feature prominently in explaining the choice of member states to share sovereign decision-making with a supranational institution, or to agree to common foreign policy actions limiting their room for manoeuvre.

Prof. Loth suggests to consider also joint leadership in the Nine's collective action. We now know that Willy Brandt, Georges Pompidou, and Edward Heath shared the vision of a politically independent Europe and influenced the development of the European project. At least for the Franco-German couple a basic understanding continued beyond the political changes of 1974, and its influence deserves further research and acknowledgment.

Given the complexity of EC polity, research in this field should be multi-national and multi-archival. To start with, foreign ministries' documents should be complemented with sources from other branches of the administration, policy-makers' private papers and, when relevant, non-governmental actors' papers. Furthermore, scholars should move beyond national sources and make full use of European institutions' documents. Beyond archival sources, academic journals of the time may provide useful insights into the political and economic debate; and journalists' reports may serve as both eyewitness accounts and critical commentaries on international relations and politics, although their accuracy should always be checked against other available material.

To conclude on methodology, I would favour some degree of openness to other disciplines. As generations of French and Italian scholars of histoire des relations internationales have learned from Jean-Baptiste Duroselle, Pierre Renouvin, and Ennio Di Nolfo, historiography significantly benefits from concepts and theories developed by political scientists, sociologists, economists, jurists. ${ }^{64}$ I envisage promis-

64. P. RENOUVIN, J.-B. DUROSELLE, Introduction ..., op.cit.; E. DI NOLFO., Prima lezione di storia delle relazioni internazionali, Laterza, Roma, 2006. 
ing outcome from a targeted use of their scholarship on matters such as economic interdependence and warfare, multilateralism, governance, decision-making.

\section{Research agenda: possible topics}

To start with, historians might look at EC "Eastern policy" as part of a more general effort at asserting an international political role of the EC, and thus analyse European polity's changing governance in this respect. In particular, and beyond national politics, development of EPC mechanism, the broadening of EC policies, the role of the European Parliament and European Council should all be taken into consideration. I would also encourage studies on the influence of the European civil society on EC/ EPC decisions. Being economic issues a most prominent part of EC's relations with Soviet bloc countries, it would be interesting to analyse the role of the industrial and business community and their attempts at influencing either national governments or EC institutions, the perceptions and responses of the latter, the actual influence on EC/EPC decisions. The same kind of approach might apply to public opinion, and particularly its most vocal parts such as human rights activists and peaceful movements, to which the CSCE process opened a formidable stage. This kind of analysis has led to fascinating results in the case of the US. ${ }^{65}$ Given the collective action of the EC-Nine in the CSCE process, it might prove equally fruitful in European studies. Scholars could also analyse attempts at promoting "European détente" further, looking at the political debate within both EPC and the Community framework. In this context, the debate on the role of economic relations, i.e. interdependence vs. economic warfare, is of major importance.

Research might also deal with the transatlantic dimension of EC policy towards the East, and focus not only on détente, but also on the debate on international trade and the possibility to involve centrally planned economies in international regimes. On the one side, the end of the Bretton Woods system, the rising rates of inflation and unemployment, the process of de-industrialisation all involved capitalist countries in attempts at rethinking international economic structures and relations. On the other side, European communist regimes were re-thinking political economy and intra-bloc trade. Both the national and Comecon debates show an increasing openness to trade and co-operation with the West, as well as a growing willingness to participate in (and possibly help refine) international economic organisations. Within this broader context, one of the key issues historians should also address is EC's attempt at gaining recognition from the communist countries. Moreover, research on this topic might take into consideration the cases of Yugoslavia and China, either in a compar-

65. S. SNYDER, Human Rights Activism and the End of the Cold War: A Transnational History of the Helsinki Network, Cambridge University Press, Cambridge, 2011. 
ative perspective or as influencing negotiations between the EC and Soviet bloc countries. ${ }^{66}$

Finally, scholars might appraise EC's policy towards the East and thus highlight the factors, whether supranational, national or international, determining both the characteristics of EC's action and the extent to which it achieved its goals. Studies on this topic might consider not only bilateral relations, but also multilateral contexts such as the CSCE process and the UN Economic Commission for Europe.

Angela Romano (Marie Curie Fellow, LSE)

66. On EC and China see the promising research of Marie-Julie Chenard, PhD candidate at LSE International History Department. 